\title{
Preliminary estimation of Lake El'gygytgyn water balance and sediment income
}

\author{
G. Fedorov ${ }^{1,2}$, M. Nolan ${ }^{3}$, J. Brigham-Grette ${ }^{4}$, D. Bolshiyanov ${ }^{2}$, G. Schwamborn ${ }^{5}$, and O. Juschus ${ }^{6}$ \\ ${ }^{1}$ Arctic and Antarctic Research Institute, Bering Street 38, 199397 St. Petersburg, Russia \\ ${ }^{2}$ St. Petersburg State University, Faculty of Geography and Geoecology, 10 line V.O., 33, 199178, St. Petersburg, Russia \\ ${ }^{3}$ Water and Environmental Research Center, Institute of Northern Engineering, 306 Tanana Drive, Duckering Room 437, \\ University of Alaska Fairbanks, Fairbanks, Alaska 99775-5860, USA \\ ${ }^{4}$ Department of Geosciences, University of Massachusetts, P.O. Box 35820, Amherst, MA 01003-5820, USA \\ ${ }^{5}$ Alfred Wegener Institute for Polar and Marine Research, Telegrafenberg, 14471 Potsdam, Germany \\ ${ }^{6}$ Institute of Applied Geology, Technical University of Berlin, Ackerstrasse 76, Sek ACK 1-1, 13355 Berlin, Germany
}

Correspondence to: G. Fedorov (fedorov@ aari.ru)

Received: 31 July 2012 - Published in Clim. Past Discuss.: 22 August 2012

Revised: 4 June 2013 - Accepted: 6 June 2013 - Published: 15 July 2013

\begin{abstract}
Modern process studies of the hydrologic balance of Lake El'gygytgyn, central Chukotka, and the sediment income from the catchment were carried out during a field campaign in spring and summer 2003. Despite high uncertainties due to the limited data, the results provide important first estimates for better understanding the modern and past sedimentation processes in this basin. Formed ca. 3.6 million years ago as a result of a meteorite impact, the basin contains one of the longest paleoclimate records in the terrestrial Arctic. Fluvial activity is concentrated over the short snowmelt period (about 20 days in second part of June). Underground outflow plays a very important role in the water balance and predominates over surface outflow. The residence time of the lake water is estimated to be about $100 \mathrm{yr}$.
\end{abstract}

\section{Introduction}

Lake El'gygytgyn is located in Central Chukotka, Far East Russian Arctic $\left(67^{\circ} 30^{\prime} \mathrm{N}, 172^{\circ} 5^{\prime} \mathrm{E}\right.$; Fig. 1), approximately $100 \mathrm{~km}$ north of the Arctic Circle. The lake is almost square in shape with a diameter of about $12 \mathrm{~km}$ in filling a portion of a meteorite impact crater, today marked at $18 \mathrm{~km}$ in diameter. The crater formed 3.6 million yr ago (Layer, 2000).

Based upon previous geomorphologic and geological research (Glushkova, 1993) the region of the crater was never glaciated and sedimentation in the enclosed lake presumably has been continuous since its formation. In the winter season of 2008-2009, deep drilling of Lake El'gygytgyn recovered long cores embracing both the entire lacustrine sediment sequence from the center of the basin $(318 \mathrm{~m})$ and a companion core into permafrost from outside the talik surrounding the lake (141.5 m, Melles et al., 2011). These cores now provide the science community with the longest terrestrial paleoenvironmental record from the Arctic, starting in the warm mid-Pliocene (Melles et al., 2012; Brigham-Grette et al., 2013).

This paper provides the results of water balance and sediment income investigations at Lake El'gygytgyn, based upon data obtained during a pre-site survey in 2003. Knowledge of modern hydrological and sediment supply processes is critically important as a baseline to interpret the sensitivity of basin sedimentology to climate forcing in the past.

The crater rim hills are formed by Upper Cretaceous rocks of volcanic origin (Belyi, 1998). They rise up to 600$930 \mathrm{~m}$ a.s.l. (above sea level). The lake level elevation according to recent topographic maps is $492.4 \mathrm{~m}$ a.s.l. Lake El'gygytgyn is located in the zone of continuous permafrost (Yershov, 1998; Schwamborn et al., 2012). The thickness of permafrost in the crater is estimated to be about $350 \mathrm{~m}$ (Mottaghy et al., 2013; Schwamborn et al., 2012). In summer 2003 the active layer varied between $0.4 \mathrm{~m}$ in silty material and $0.8 \mathrm{~m}$ in sand and gravel (Schwamborn et al., 2012). The Crater region belongs to the hypoarctic tundra vegetation 


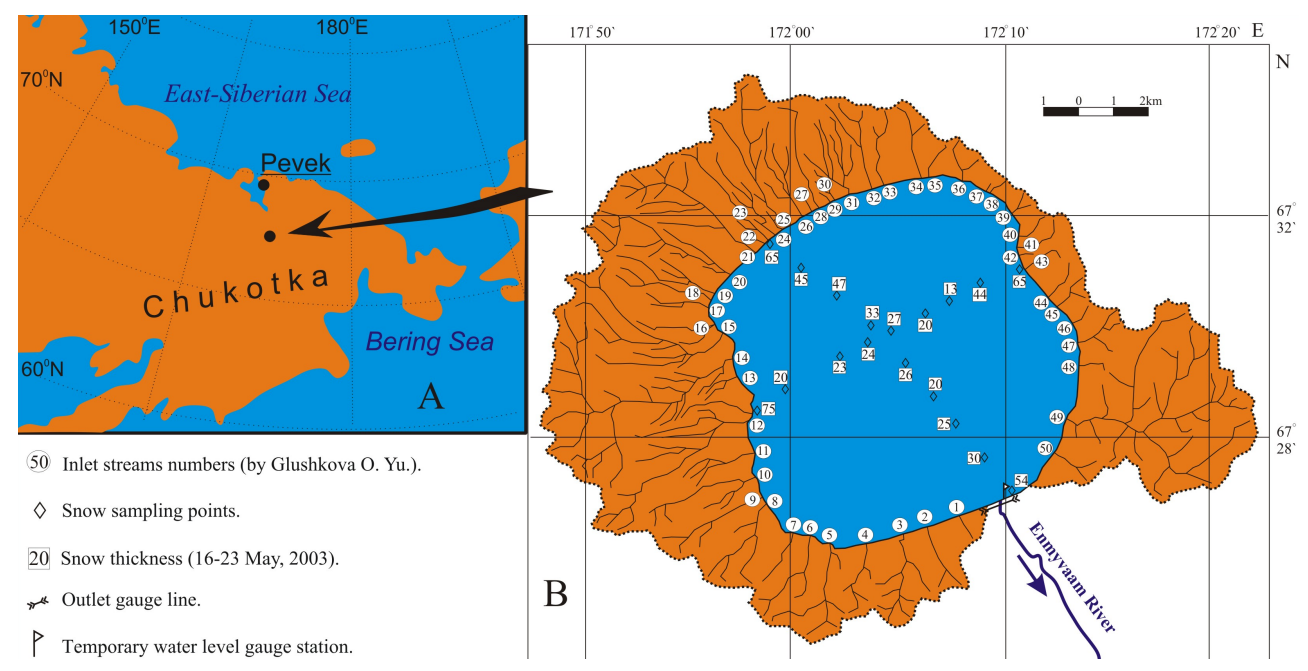

Fig. 1. Location (a) and scheme (b) of the Lake El'gygytgyn drainage basin.

zone (Yurtsev, 1973) with discontinuous cover dominated by lichen and herbaceous taxa (Kohzevnikov, 1993; Minyuk, 2005; Lozhkin et al., 2006; Wilkie et al., 2013).

An overview of the lake's setting, basin morphologic parameters, modern meteorological characteristics and lake crater hydrology were first provided by Nolan and BrighamGrette (2007). Lake El'gygytgyn is a monomictic, and ultraoligotrophic lake with an area of $110 \mathrm{~km}^{2}$, a volume of $14.1 \mathrm{~km}^{3}$, and a maximum water depth of $175 \mathrm{~m}$. It is surrounded by a watershed measuring $293 \mathrm{~km}^{2}$ (Nolan and Brigham-Grette, 2007). The lake has approximately 50 inlet streams and one outlet, the Enmyvaam River (Fig. 1) that belongs to the Anadyr River drainage basin leading to the Bering Sea.

Data from an automated meteorological station installed at the southern lake shore near the outflow river in 2000 (Nolan and Brigham-Grette, 2007; Nolan, 2012) shows that over the period from 2001 to 2009 the average air temperature was $-10.2^{\circ} \mathrm{C}$ with extremes from $-40^{\circ} \mathrm{C}$ to $+28^{\circ} \mathrm{C}$. The mean annual amount of liquid precipitation during $6 \mathrm{yr}$ over the period from 2002 to 2007 was $126 \mathrm{~mm}$ with extremes from $70 \mathrm{~mm}$ in 2002 to $200 \mathrm{~mm}$ in 2006 (Nolan, 2012). The onset of spring flooding and first motes of open water typically appear along the lake shore in the beginning of June. Lake ice completely disappears in the middle of July and freezing starts again by the middle of October (Nolan et al., 2003). Notably timing is everything, given that the outlet is closed until late June when the lake level rises enough to breach and quickly downcut through the fall season longshore drift choking the outlet. Moreover, during the course of most summers inlet streams are largely reduced to a trickle or dry up completely after the late spring freshet.

A first appraisal of the Enmyvaam River discharge velocity at its head was done by Glotov and Zuev (1995). Velocities nearly equal to $1 \mathrm{~m} \mathrm{~s}^{-1}$ allowed them to estimate a max- imum water discharge of $50 \mathrm{~m}^{3} \mathrm{~s}^{-1}$, but an average in the range of $20 \mathrm{~m}^{3} \mathrm{~s}^{-1}$ (Glotov and Zuev, 1995).

\section{Methods}

\subsection{Water balance}

The following equation can be applied to estimate Lake El'gygytgyn water balance:

$\frac{\mathrm{d} V}{\mathrm{~d} t}=\left(Y_{1}+Y_{2}\right)+P+Z_{1}-Z_{2}-E-Y$,

where $V=$ Lake water volume; $t=$ time period; $Y_{1}=$ inflow by main lake tributaries; $Y_{2}=$ inflow by remaining stream network; $P=$ precipitation over the lake surface; $Z_{1}=$ underground inflow; $Z_{2}=$ underground outflow; $E=$ evaporation from the open-water surface; $Y=$ outflow by Enmyvaam River.

\subsubsection{Enmyvaam River, main lake tributaries and remaining stream network runoffs}

During summer 2003 the water discharges in the Enmyvaam River (outflow) and main inlet streams (Fig. 1) were measured three times at the beginning, middle and end of the summer season (Table 1). A standard current velocity meter was used to measure flow rates.

The water discharge was calculated according to the prescribed analytical method (Guide to Hydrometeorological Stations, 1978). Average seasonal water discharge and subsequently seasonal runoff were then calculated for each measured stream.

The stream's watershed area provided by Nolan and Brigham-Grette (2007) was used to calculate the unit area discharge (ratio between the water runoff and watershed area) for all main streams. 
Table 1. Water and sediment discharge measured during spring and summer 2003 in the outlet river and inlet streams, Lake El'gygytgyn.

\begin{tabular}{|c|c|c|c|c|c|c|c|c|c|}
\hline Site & Date & $\begin{array}{c}\text { Water } \\
\text { discharge } \\
\mathrm{m}^{3} \mathrm{~s}^{-1}\end{array}$ & $\begin{array}{c}\text { Sediment } \\
\text { discharge } \\
\mathrm{g} \mathrm{s}^{-1}\end{array}$ & Date & $\begin{array}{c}\text { Water } \\
\text { discharge } \\
\mathrm{m}^{3} \mathrm{~s}^{-1}\end{array}$ & $\begin{array}{c}\text { Sediment } \\
\text { discharge } \\
\mathrm{g} \mathrm{s}^{-1}\end{array}$ & Date & $\begin{array}{c}\text { Water } \\
\text { discharge } \\
\mathrm{m}^{3} \mathrm{~s}^{-1}\end{array}$ & $\begin{array}{c}\text { Sediment } \\
\text { discharge } \\
\mathrm{g} \mathrm{s}^{-1}\end{array}$ \\
\hline Enmyvaam River & 3 July 2003 & 12.807 & 106.022 & 17 July 2003 & 15.271 & 75.670 & 10 August 2003 & 9.053 & 62.527 \\
\hline creek 50 & 12 June 2003 & 0.580 & 6.678 & $\mathrm{n}$ & & & $\mathrm{n}$ & & \\
\hline creek 49 & 12 June 2003 & 6.094 & 23.955 & 23 July 2003 & 0.058 & 0.138 & 18 August 2003 & 0.359 & 0.329 \\
\hline creek 47 & 18 June 2003 & 0.140 & 0.351 & 23 July 2003 & 0.018 & 0.030 & 18 August 2003 & 0.018 & \\
\hline creek 44 & $\mathrm{n}$ & & & 23 July 2003 & 0.020 & 0.165 & $\mathrm{n}$ & & \\
\hline creek 45 & $\mathrm{n}$ & & & $\mathrm{n}$ & & & 18 August 2003 & 0.158 & 0.164 \\
\hline creek 41 & 18 June 2003 & 0.220 & 0.266 & 23 July 2003 & 0.015 & 0.190 & 18 August 2003 & 0.013 & 0.010 \\
\hline creek 36 & $\mathrm{n}$ & & & $\mathrm{n}$ & & & 18 August 2003 & 0.034 & 0.113 \\
\hline creek 35 & $\mathrm{n}$ & & & $\mathrm{n}$ & & & 18 August 2003 & 0.064 & 0.260 \\
\hline creek 34 & $\mathrm{n}$ & & & 23 July 2003 & 0.019 & 0.021 & 18 August 2003 & 0.072 & 0.225 \\
\hline creek 33/1 & $\mathrm{n}$ & & & $\mathrm{n}$ & & & 18 August 2003 & 0.066 & 0.062 \\
\hline creek 33 & 18 June 2003 & 0.170 & 0.599 & 23 July 2003 & 0.022 & & 18 August 2003 & 0.073 & 0.035 \\
\hline creek 32 & $\mathrm{n}$ & & & 23 July 2003 & 0.052 & 0.052 & 18 August 2003 & 0.116 & 0.133 \\
\hline creek 31 & $\mathrm{n}$ & & & $\mathrm{n}$ & & & 18 August 2003 & 0.249 & 0.333 \\
\hline creek 28 & $\mathrm{n}$ & & & $\mathrm{n}$ & & & 18 August 2003 & 0.048 & 0.083 \\
\hline creek 27 & $\mathrm{n}$ & & & $\mathrm{n}$ & & & 18 August 2003 & 0.028 & 0.026 \\
\hline creek 26 & $\mathrm{n}$ & & & 23 July 2003 & 0.006 & 0.583 & 18 August 2003 & 0.029 & 0.015 \\
\hline creek 25 & $\mathrm{n}$ & & & 23 July 2003 & 0.026 & 0.223 & 18 August 2003 & 0.055 & 0.114 \\
\hline creek 23 & $\mathrm{n}$ & & & 23 July 2003 & 0.516 & 1.351 & 18 August 2003 & 0.122 & 0.023 \\
\hline creek 21 & 19 June 2003 & 1.720 & 5.867 & 23 July 2003 & 0.044 & 0.083 & 19 August 2003 & 0.094 & \\
\hline creek 20 & $\mathrm{n}$ & & & 24 July 2003 & 0.068 & 0.298 & 19 August 2003 & 0.105 & 0.157 \\
\hline creek 19 & $\mathrm{n}$ & & & $\mathrm{n}$ & & & 19 August 2003 & 0.033 & 0.025 \\
\hline creek 16 & $\mathrm{n}$ & & & 24 July 2003 & 0.036 & 0.160 & 19 August 2003 & 0.072 & 0.206 \\
\hline creek 14 & 19 June 2003 & 1.305 & 17.879 & 24 July 2003 & 0.093 & 0.026 & 19 August 2003 & 0.152 & 0.397 \\
\hline creek 12 & $\mathrm{n}$ & & & 24 July 2003 & 0.010 & 0.017 & 19 August 2003 & 0.035 & 0.046 \\
\hline creek 10 & $\mathrm{n}$ & & & 24 July 2003 & 0.005 & 0.014 & 19 August 2003 & 0.083 & 0.162 \\
\hline creek 8 & $\mathrm{n}$ & & & 24 July 2003 & 0.017 & 1.248 & 19 August 2003 & 0.014 & 0.006 \\
\hline creek 7 & $\mathrm{n}$ & & & 24 July 2003 & 0.012 & & 19 August 2003 & 0.003 & 0.009 \\
\hline creek 6 & $\mathrm{n}$ & & & 24 July 2003 & 0.003 & 0.013 & 19 August 2003 & 0.005 & 0.000 \\
\hline creek 5 & $\mathrm{n}$ & & & 24 July 2003 & 0.002 & & 19 August 2003 & 0.009 & 0.020 \\
\hline creek 4 & $\mathrm{n}$ & & & 24 July 2003 & 0.002 & 0.002 & 19 August 2003 & 0.003 & 0.010 \\
\hline creek 3 & 15 June 2003 & 0.140 & 1.036 & $\mathrm{n}$ & & & $\mathrm{n}$ & & \\
\hline creek 2 & 15 June 2003 & 0.060 & 0.107 & $\mathrm{n}$ & & & $\mathrm{n}$ & & \\
\hline
\end{tabular}

$\mathrm{n}$ - no measurements.

The sequence of total seasonal surface inflow

( $W=Y_{1}+Y_{2}$, see Eq. 1$)$ was estimated by

$M_{i_{j}}=\frac{Q_{i_{j}}}{F_{i}}$,

where $M_{i_{j}}$ is the unit area discharge from the watershed area of stream - " $i$ " for measurement series - " $j "\left(\mathrm{~m}^{3} \mathrm{~s}^{-1}\right.$ $\left.\mathrm{km}^{-2}\right) ; Q_{i_{j}}$ is the water discharge of stream - " $i$ " for measurement series - " $j$ " $\left(\mathrm{m}^{3} \mathrm{~s}^{-1}\right) ; i$ - ordinal number of incoming stream; $j$ - ordinal number of water discharge measurements series; $F_{i}$ is the watershed area of stream - " $i "\left(\mathrm{~km}^{2}\right)$.

$M_{\mathrm{m}_{j}}=\frac{1}{n_{j}} \sum_{i=1}^{n_{j}} M_{i_{j}}$

where $M_{\mathrm{m}_{j}}$ is the average unit area discharge for measurement series - " $j "\left(\mathrm{~m}^{3} \mathrm{~s}^{-1} \mathrm{~km}^{-2}\right) ; n_{j}$ is the number of measured streams for measurement series - " $j$ " $\left(n_{1}=9, n_{2}=21\right.$, $\left.n_{3}=28\right)$.

$Q_{j}=F * \frac{1}{3} \sum_{j=1}^{3} M_{\mathrm{m}_{j}}$,

where $Q_{j}$ is water discharge from the entire watershed area $(F)$ for measurement series - “ $j "\left(\mathrm{~m}^{3} \mathrm{~s}^{-1}\right)$.

$W=T * \frac{1}{3} \sum_{j=1}^{3} Q_{j}$,

where $T$ is the duration of the estimate period. The beginning of the estimate period was placed on the date we first visually recognized water flow at stream mouths in 2003 (1012 June). At the very beginning of October when our automated meteorological station recorded the onset of active layer freezing (see Fig. 2), we marked as the end of estimate period. Thus, the duration of our estimate period was considered to be 110 days. 

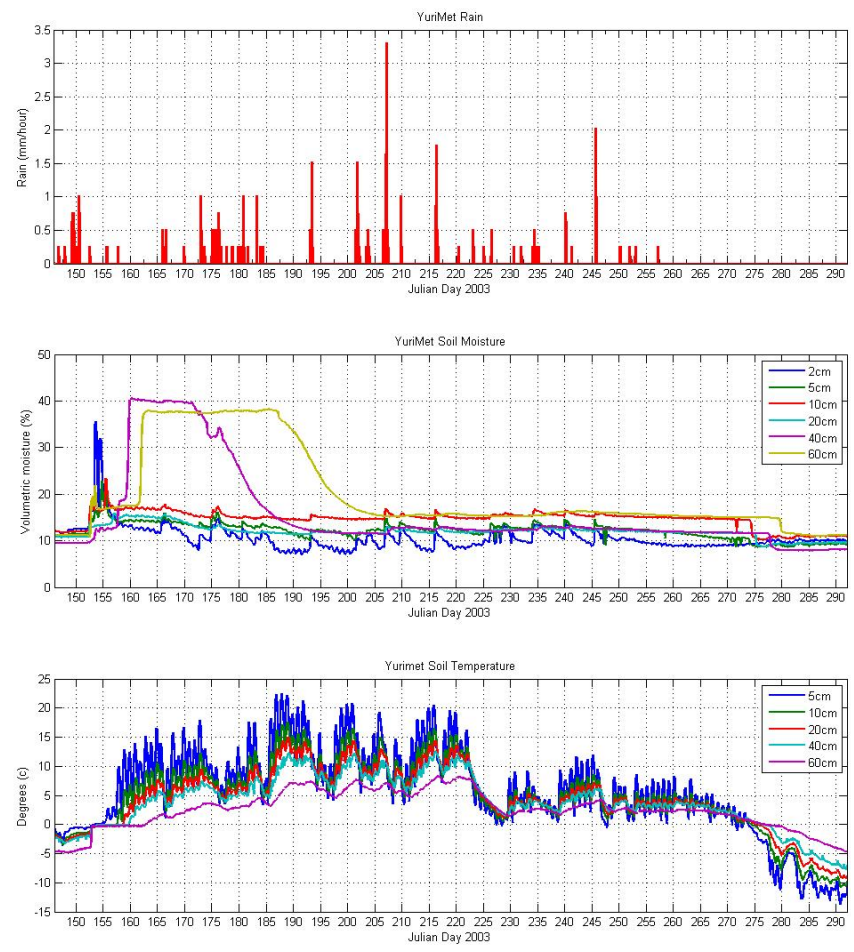

Fig. 2. Rain, soil moisture and soil temperature for 2003. Surface soils thaw between day 150-155 (end of May), with energy from the sun, snowmelt, and rain. Within a week the deeper soils thaw. The surface soils begin drying out quickly once thawed, but a water table persists for several weeks between 20 and $40 \mathrm{~cm}$ depth, indicating water storage, likely from snowmelt and early rain as the soils at depth were dry at the end of the previous summer. This water drains about the time the outlet river opens up in early July. Variations after this point are caused by rainfall, which do reach the $40 \mathrm{~cm}$ level quickly, indicating good hydraulic conductivity. Soils then freeze with little trapped moisture between days 273-280 (early October).

The Enmyvaam River total runoff was estimated as the average water discharge multiplied by time period of outflow activity. In 2003 the outflow into the Enmyvaam River system opened on 3 July and closed by storm on 14 August.

\subsubsection{Precipitation over the lake surface}

Precipitation over the lake surface was estimated as the sum of liquid precipitation directly to the lake water surface during summer plus the melted snow supplied from the seasonal lake ice. The data about summer liquid precipitations was extrapolated from the automatic weather station installed in southern lake shore in 2000 (Nolan and Brigham-Grette, 2007).

To estimate the supply of the melted snow derived from on top of the lake ice, a snow survey of the lake ice surface was performed in spring 2003 (Fig. 1). The snow thickness was measured and snow samples were taken using an express volume sampling device (Guide to Hydrometeorological Stations, 1978).

\subsubsection{Groundwater components of the water balance}

The most difficult parameters to estimate in this basin are the groundwater components. We had no means of estimating underground inflow from the catchment directly into the lake, however, it could be quite significant as shown for other areas (Zhang et al., 2003; Woo et al., 2008). For instance, at Levinson-Lessing Lake, located on the Taymyr Peninsula, Central Siberia in similar climate and permafrost conditions (Zimichev et al., 1999), the underground inflow was determined to be about $15 \%$ of total water yield, based upon the difference between the outflow river runoff plus evaporation and all the other components of water income (Zimichev et al., 1999). At Lake El'gygytgyn, however, both positive and negative portions of the water balance can have unknown groundwater components. As a result, the contribution of underground in- or outflow to the water balance was estimated jointly as the difference between the known terms of the equation.

\subsubsection{Evaporation from the open-water surface}

Evaporation from the lake surface was also difficult to quantify. Within the accuracy of our empirical data we chose to use regional open-water evaporation data from Sokolov (1964). Sokolov (1964) provided standard maps of evaporation from open-water surface based on observations on all available meteorological stations. Across the region of Chukotka, 27 of meteorological stations were taken into consideration.

\subsubsection{Water level change measurements}

During spring and summer field work in 2003, measurements of the water level were carried out at the south-eastern shore of the lake and in the river outflow (Fig. 1). A temporary graduated staff gauge for visual water level observations was installed after the first motes and leads of ice-free water appeared along the lake shore (10-15 June). Lake level changes were monitored from 14 June to 19 August (Fig. 3) with measurement gaps only during ice jams at the beginning of the season, and during strong storms at the end of the field campaign. The lake ice completely disappeared finally on 19 July.

Another graduated staff gauge for visual water level observations was installed $100 \mathrm{~m}$ downstream of Enmyvaam River from the lake shore. At this location, water flowed in the river channel well before opening and after closing of the direct surface outflow due to the infiltration of lake water through the porous gravel deposits of the coastal levee. The river level changes were monitored from 14 June to 16 August (Fig. 3) or slightly longer than the period of surface outflow activity. 


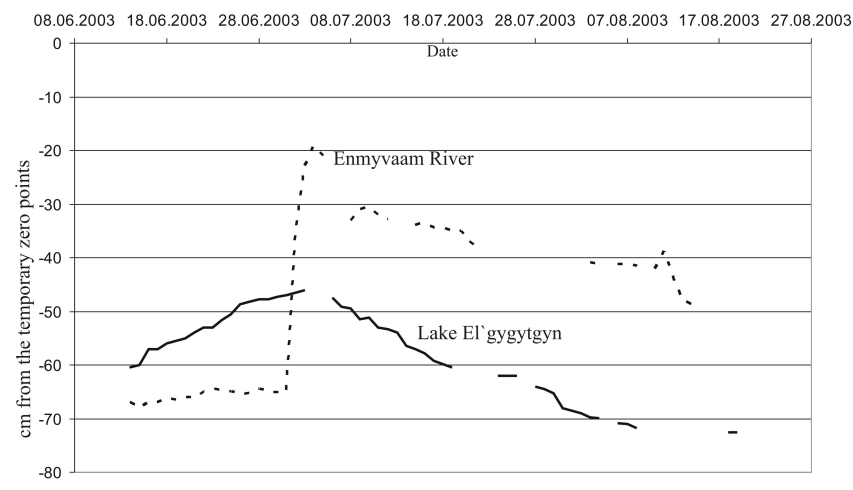

Fig. 3. Water level changes in Lake El'gygytgyn (solid line) and Enmyvaam River (dashed line) during summer 2003. Lake and river level measurements had two different temporary zero points.

\subsubsection{Residence time of the water in Lake El'gygytgyn}

The residence time of the water in Lake El'gygytgyn was estimated as the ratio between the total lake water volume and the water supply volume for one year (using the data for 2003).

\subsection{Sediment income}

Our data did not allow us to estimate the sediment balance of Lake El'gygytgyn; rather the data we have provide important quantitative information about fluvial and aeolian sediment income.

\subsubsection{Fluvial sediment supply}

Water samples were collected simultaneously with water discharge measurements by so-called integral method (through entire water column). Turbidity was determined after filtration through paper filters (standard so-called "yellow stripe" filters used in Russian hydrometeorological survey) at the bottom of a "Kuprin" device having a diameter of $10 \mathrm{~cm}$. The filters were pre-weighed before the expedition and repeatedly after with foregoing drying. Drying was performed for a duration of $6 \mathrm{~h}$ in a laboratory oven maintained at $60^{\circ} \mathrm{C}$.

Knowledge about turbidity and water discharge allowed us to calculate sediment discharges.

Total seasonal sediment inflow from the entire watershed area was calculated based on Eqs. (6) to (10).

$A_{i_{j}}=Q_{i_{j}} * C_{i_{j}}$

where $A_{i_{j}}$ is the sediment discharge of stream - " $i$ " for measurement series - " $j$ " $\left(\mathrm{g} \mathrm{s}^{-1}\right) ; C_{i_{j}}$ is the concentration of suspended particles of stream - " $i$ " for measurement series - " $j$ " $\left(\mathrm{g} \mathrm{m}^{-3}\right)$.

$\mathrm{MA}_{i_{j}}=\frac{A_{i_{j}}}{F_{i}}$ where $\mathrm{MA}_{i j}$ is the unit area sediment discharge from the watershed area of stream - " $i$ " for measurement series - " $j$ " $\left(\mathrm{g} \mathrm{s}^{-1} \mathrm{~km}^{-2}\right)$.

$\mathrm{MA}_{\mathrm{m}_{j}}=\frac{1}{n_{j}} \sum_{i=1}^{n_{j}} \mathrm{MA}_{i_{j}}$,

where $\mathrm{MA}_{i_{j}}$ is the average unit area sediment discharge for measurement series - “ $j$ ” $\left(\mathrm{g} \mathrm{s}^{-1} \mathrm{~km}^{-2}\right)$.

$A_{j}=F * \frac{1}{3} \sum_{j=1}^{3} \mathrm{MA}_{\mathrm{m}_{j}}$,

where $A_{j}$ is sediment discharge from entire lake watershed area $(F)$ for measurement series - " $j "\left(\mathrm{~g} \mathrm{~s}^{-1}\right)$.

$A_{\text {in }}=T * \frac{1}{3} \sum_{j=1}^{3} A_{j}$,

where $A_{\text {in }}$ is the total seasonal sediment inflow from entire lake watershed area $(\mathrm{g})$.

Using the same approach water samples were also taken from the Enmyvaam River simultaneously with water discharge measurements with subsequent calculation of sediment discharges (Table 1). But these data could not be used for the sediment outflow estimation (see Sect. 3.2.2).

\subsubsection{Aeolian sediment input}

Aeolian input to the lake surface was estimated only for the winter season by measuring particle concentrations in the snow cover collected from the lake ice surface. The collected snow samples (see Sect. 2.1.2) were melted and filtered as described in Sect. 2.2.1.

\section{Results and discussion}

\subsection{Water balance}

\subsubsection{Water surface inflow and outflow}

First instrumental measurements of water discharge were performed in summer 2000 (Nolan and Brigham-Grette, 2007). For this study, measurements were done three times at the Enmyvaam River head and once in most of the inlet streams to Lake El'gygytgyn. Water discharge in the Enmyvaam River was $19.8 \mathrm{~m}^{3} \mathrm{~s}^{-1}$ on 16 August, $14.2 \mathrm{~m}^{3} \mathrm{~s}^{-1}$ on 23 August, and $11.6 \mathrm{~m}^{3} \mathrm{~s}^{-1}$ on 1 September; meanwhile we measured less than $1 \mathrm{~m}^{3} \mathrm{~s}^{-1}$ in all the inlet streams. These data are not directly incorporated into our presented water balance because they are only valid for the end of hydrological season in 2000; however, the numbers are similar and therefore, comparable to what was measured at the end of the 2003 season (Table 1). 
Water and sediment discharges were measured at the head of the Enmyvaam River and in selected inlet streams around the Lake El'gygytgyn basin three times during the summer 2003 (Table 1). The lake and Enmyvaam River level changes were monitored from 14 June to 19 August (Fig. 3).

The water level in both the river and the lake basin are at a maximum at the end of the snowmelt period, coincident with the opening of the Enmyvaam River at the end of June. During autumn (August/September), with the general lowering of the lake level accompanied by northern winds, storms carrying gravel form a levee along the southern shore that impedes the outflow into the Enmyvaam River. In springtime this levee is destroyed by similar storms concurrent with the rise of the lake level, leading to the restitution of the river flow.

The total amplitude of lake-level changes during the measurement period was $26.5 \mathrm{~cm}$ (Fig. 3). However, it is obvious that lake-level change directly controls the levels of the Enmyvaam River, which fluctuated in amplitude by almost $90 \mathrm{~cm}$ during the measurement period. During the summer of 2003, before breaching of the outlet levee (i.e., prior to 3 July), the level of Lake El'gygytgyn rose steadily at an average rate of about $0.8 \mathrm{~cm}$ per day. The highest rates $(3 \mathrm{~cm}$ and $1.2-1.8 \mathrm{~cm}$ per day) were recorded on 16 June and $23-$ 26 June. With the onset of the annual discharge through the river, the level of the lake subsequently dropped at an average rate of $0.7 \mathrm{~cm}$ per day coincident with the downcutting of the outlet channel.

The 50 major streams entering Lake El'gygytgyn are numbered according to a system first proposed by O. Yu. Glushkova (unpublished data). The first measurements of water and sediment discharge in selected inlet streams were initiated at the onset of snowmelt in the middle of June 2003. They were repeated in July, and again at the end of the field season in the middle of August. The results illustrate two important points. First, water and sediment discharge vary widely between individual streams, and over time (Table 1). Secondly, both the water and sediment delivery into the lake takes place over a short time span during the snowmelt, when the input of both water and suspended sediment load is an order of magnitude higher than that during summer.

The Lake El'gygytgyn water balance components for 2003 are summarized in Table 2 and Fig. 4. The total annual water inflow by inlet streams is $0.11 \mathrm{~km}^{3}$ and outflow at the Enmyvaam River headwaters is $0.05 \mathrm{~km}^{3}$, indicating that either the lake was storing more water or that evaporation and groundwater leakage are important fluxes in the lake mass balance.

\subsubsection{Water supply from the lake ice surface}

Prior to snowmelt during spring 2003 (16 May and 23 May), snow sampling was performed to estimate the water supply derived from the lake ice surface (see Fig. 1). The snow thickness averaged $35.6 \mathrm{~cm}$ within a range from 13 to $75 \mathrm{~cm}$ at a

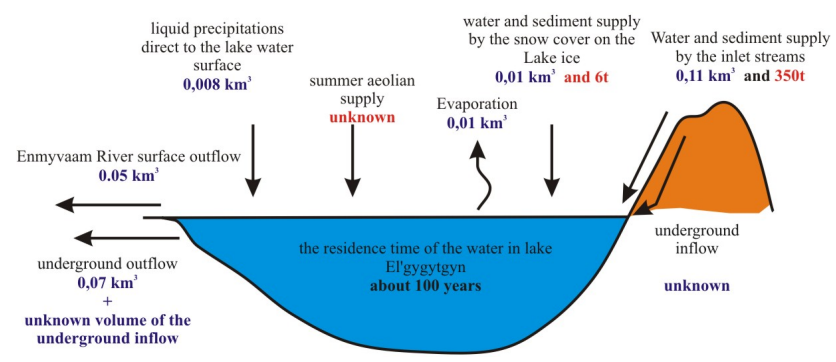

Fig. 4. Sketch of Lake El'gygytgyn water balance and sediment flux.

snow density averaging $0.29 \mathrm{~g} \mathrm{~L}^{-1}$ within a range from 0.1 to $0.4 \mathrm{~g} \mathrm{~L}^{-1}$. These data provided the means of estimating the water supply from the snowpack at $0.01 \mathrm{~km}^{3} \mathrm{a}^{-1}$ (Table 2).

\subsubsection{Liquid precipitation to the lake water surface}

The contribution of rainfall precipitation to the lake during summer can be estimated using data from an automatic weather station at the southern lake shore (Fig. 2, Nolan, 2012). According to these data, during summer 2003 the amount of rainfall was $73 \mathrm{~mm}$, suggesting a total of $0.008 \mathrm{~km}^{3}$ of additional water to the lake surface (Fig. 4, Table 2). Over the $7 \mathrm{yr}$ of instrumental measurements at the lake, the maximum recorded summer rainfall was $200 \mathrm{~mm}$, or nearly 3 times larger than observed in 2003. Given that the rain gauge was not shielded from the wind, these numbers are probably conservative.

\subsubsection{Underground runoff and evaporation}

The complete 2003 annual water input was approximately $0.13 \mathrm{~km}^{3}$ excluding an unknown amount of underground input, but the total Enmyvaam River outflow was only $0.05 \mathrm{~km}^{3}$ (Table 2, Fig. 4). Consequently, a significantly higher volume of water must have been lost due to underground runoff and/or evaporation, since lake level (and therefore water storage) dropped during the observation period.

According to Sokolov (1964) the annual evaporation from lakes like El'gygytgyn across this territory is estimated to be $10 \mathrm{~cm}$ per year. Thus, we can roughly estimate the annual evaporation for Lake El'gygytgyn as $0.01 \mathrm{~km}^{3}$ (Table 2), i.e., up to $10 \%$ of the total water discharge.

The water level observations in Lake El'gygytgyn and the Enmyvaam River (Fig. 3, Table 2) demonstrate the important role of underground outflow. For a raising or lowering of the lake water level by $1 \mathrm{~cm}$, about $0.001 \mathrm{~km}^{3}$ of water is required. Thus, using available daily lake water-level dynamics and calculated average daily water supply we can estimate the average daily total lake water discharge by all factors. Data from Table 2 clearly show that underground outflow plays an important role in spring as well as in summer, and becomes more important as lake level rises. 
Table 2. Lake El'gygytgyn water balance components in 2003.

\begin{tabular}{|c|c|c|c|c|c|c|c|}
\hline $\begin{array}{l}\text { Time period in } 2003 \\
(\mathrm{~d} t)\end{array}$ & $\begin{array}{l}\mathrm{d} V / \mathrm{d} t \text { from } \\
\text { lake level } \\
\text { observations } \\
\left(\mathrm{km}^{3}\right)\end{array}$ & $\begin{array}{l}\text { Inflow } \\
\left(Y_{1}+Y_{2}\right) \\
\left(\mathrm{km}^{3}\right)\end{array}$ & $\begin{array}{l}\text { Precipitations } \\
\text { on lake } \\
\text { surface } \\
(P)\left(\mathrm{km}^{3}\right)\end{array}$ & $\begin{array}{l}\text { Surface } \\
\text { outflow } \\
(Y)\left(\mathrm{km}^{3}\right)\end{array}$ & $\begin{array}{l}\text { Evaporation } \\
(E)\left(\mathrm{km}^{3}\right)\end{array}$ & $\begin{array}{l}\text { Ground- } \\
\text { water } \\
\text { inflow } \\
\left(Z_{1}\right)\end{array}$ & $\begin{array}{l}\text { Ground- } \\
\text { water outflow } \\
\text { from balance } \\
\left(Z_{2}\right)\left(\mathrm{km}^{3}\right)\end{array}$ \\
\hline $\begin{array}{l}\text { Period from onset of } \\
\text { snowmelt to opening } \\
\text { the outflow } \\
\text { (10 June-3 July) }\end{array}$ & +0.02 & 0.06 & & 0 & & Unknown & $\begin{array}{l}0.04-E+ \\
Z_{1}+P\end{array}$ \\
\hline $\begin{array}{l}\text { Period from opening } \\
\text { the outflow to freez- } \\
\text { ing of active layer } \\
\text { ( } 3 \text { July-1 October) }\end{array}$ & -0.03 & 0.05 & & 0.05 & & Unknown & $\begin{array}{l}0.03-E+ \\
Z_{1}+P\end{array}$ \\
\hline 2003 & 0 & 0.11 & $\begin{array}{l}0.008 \text { as } \\
\text { rainfall, } \\
0.01 \text { as } \\
\text { snow }\end{array}$ & 0.05 & 0.01 & Unknown & $0.07+Z_{1}$ \\
\hline
\end{tabular}

It is also important to note that if precipitation is low during winter and, hence, there is little rise of the lake level in spring, there may be some years without direct outflow from the lake into the Enmyvaam River, especially without strong northerly winds in spring or summer to assist with outlet erosion.

The recent erosion rate of the outflow threshold can be assumed to be minor because it is covered by several metres of lacustrine-fluvial sediments (Fedorov et al., 2008). Nevertheless, the lake does lose water through these porous deposits even during the winter season as is indicated by the annual formation of aufeis on Enmyvaam River (ice body that forms as a result of ground water discharging onto the surface during freezing temperatures), a typical phenomon observed both in the field (2008/2009) and on satellite images.

Our automated weather station provides some direct information of water transport and storage through the gravels. The station is sited about $200 \mathrm{~m}$ from the lake outlet, on an older floodplain about $20 \mathrm{~cm}$ higher than the outlet. Soil moisture and soil temperature probes were placed in a pit to a depth of $60 \mathrm{~cm}$ and the pit backfilled; these probes remained active for $7 \mathrm{yr}$ and provide a record of local water table and the timing of subsurface thaw and water movement (Figs. 2 and 5). In each year, the ground thawed to $60 \mathrm{~cm}$ depth several weeks before the outlet river opened. Further, the deeper gravels were always fully saturated after spring snowmelt, and this water drained laterally or to deeper layers by late June or early July, indicating that substantial subsurface flow of water occurred. By late summer, it was typically the case that the gravels were dry at all depths and froze this way. However, after the particularly wet summer of 2006, the soils at all depths were fully saturated and froze when filled with water. Freezing levels did not penetrate as deeply
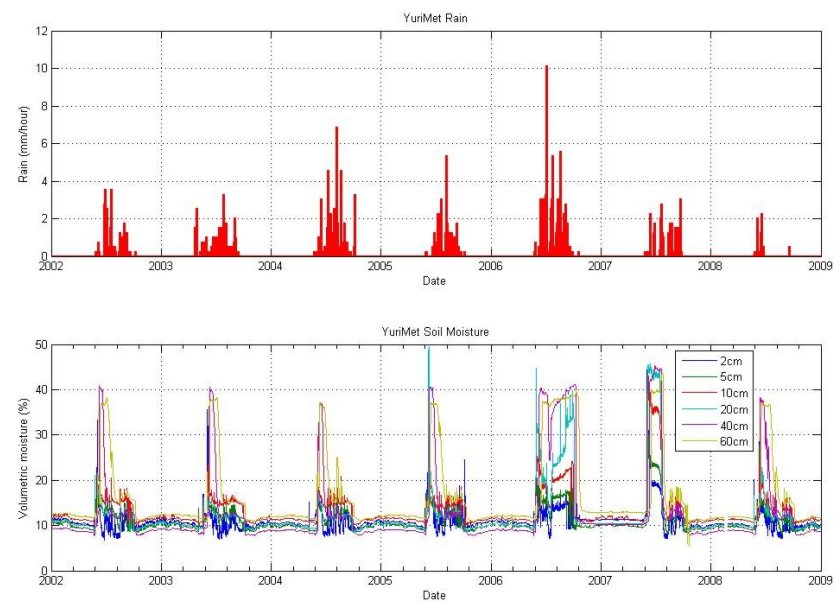

Fig. 5. Seven years of rain and soil moisture data from the outwash plain of Lake El'gygytgyn. Rain fall, as measured by a tipping bucket, occurs mainly during the summer months of June, July and August, varying from 70, 73, 173, 106, 200 and $134 \mathrm{~mm}$ from 2002 to 2007. The gauge apparently malfunctioned in June 2008. Soil moisture follow similar trends each year, except in 2006, when high rainfall left soils saturated at the end of summer. The moisture then froze and drained off the following summer. We believe these dynamics strongly support our conclusions that significant amounts of lake water can be stored in and migrate through these gravels, as described in the text.

in this winter due to the heat released by freezing the water, and in spring the water thawed in place and remained saturated for several weeks until it drained off below the surface. Thus we have direct evidence for subsurface water movement and storage within this outwash plain related to rain and snowmelt, and have no reason to doubt that similar water 
movement and storage is occurring at much larger volumes related to subsurface drainage of lake water at the outflow. We suspect that most of this flow is beneath the outlet river itself, because (1) the river bed is likely fully saturated and thus limits active layer thickness, (2) this is the topographical low, and (3) aufeis forms downstream within this channel where the pressure gradient brings the water to the surface again in the descending channel.

\subsubsection{Residence time of the water in Lake El'gygytgyn}

All the data provided above allow us to roughly estimate the average hydraulic residence time of the lake to about $100 \mathrm{yr}$ (Fig. 4). Obviously the usage of data obtained for one year only causes very significant uncertainty for an average picture. Our estimation of residence time of the water in Lake El'gygytgyn thus is exceedingly approximate but provides an essential base line for paleoenvironmental interpretations and future balance investigations.

\subsection{Sediment income}

\subsubsection{Fluvial sediment supply}

Sediment supply to the lake by inlet streams during spring and summer 2003 is estimated at roughly $350 \mathrm{t}$ (Fig. 4).

\subsubsection{Enmyvaam River sediment discharge}

In 2003 we placed the gauge line in Enmyvaam River for water discharge measurements $100 \mathrm{~m}$ downstream from the lake shore. Concentrations of suspended particles during measurements were quite high and calculated sediment discharges are significant (see Table 1). These numbers, however, cannot be used for the estimation of total sediment outflow, because the reason for such significant turbidity is probably a function of active riverbed erosion on the way from the lake to the gauge line. This erosion was annually compensated for by the active accumulation of gravel in autumn during the coastal levee formation and closing the outflow. Thus the average annual erosion rate of the outflow threshold is very low as it is discussed in Sect. 3.1.4.

The maximum water discharge down the Enmyvaam River $\left(15.27 \mathrm{~m}^{3} \mathrm{~s}^{-1}\right)$, documented during the middle of July 2003, did not coincide with maximum sediment discharge and the peak of lake level or that of the river itself (Fig. 3 and Table 1). Instead, the maximum discharge occurred during the lake level lowering. This discrepancy is due to the active erosion and enlargement of the outlet channel during the period of major water discharge into the Enmyvaam River.

This interpretation is supported by the data illustrated in Fig. 6, showing a general drop of the lake/river level coincident with a significant deepening of the riverbed. The maximum sediment discharge $\left(106.02 \mathrm{~g} \mathrm{~s}^{-1}\right)$ took place in early July, with the initiation of riverbed erosion.

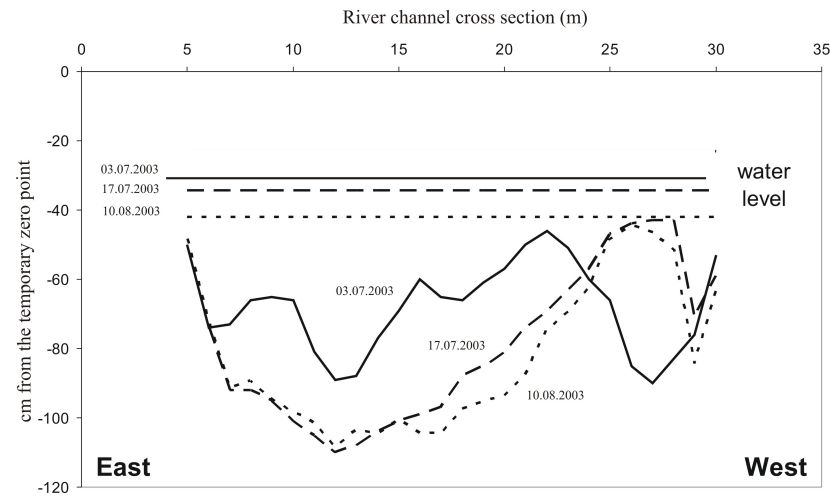

Fig. 6. Depth measurements across the channel at the head of Enmyvaam River during summer 2003, compared to the river water levels at the respective times.

\subsubsection{Aeolian sediment input}

The average concentration of solids in the snow pack on the lake ice surface was about $0.6 \mathrm{mg}$ per litre of melted water. The values ranged from 0.05 to $1.32 \mathrm{mg} \mathrm{L}^{-1}$. Taking into account the data provided in Sect. 3.1.2, this allowed us to estimate the total sediment income from the lake ice cover to about $6 \mathrm{t}$, which is less than $2 \%$ of the fluvial sediment supply.

The aeolian sediment supply during summer is unknown. The summer season in central Chukotka is very short (4 months at maximum for open-water period and even less time for positive temperatures); however, aeolian influx can be rather high considering the large snow-free area of the lake catchment. The bulk of aeolian input in the summer is most likely associated with storm events, when fine-grained, shoreline material is fed into the lake by aeolian transport. Aeolian material is additionally derived from the crater and reworked by fluvial and coastal processes. Furthermore, original aeolian material accumulates every year in the catchment and is subsequently transported into the lake by fluvial processes. Based on our data we cannot subdivide aeolian input from total fluvial supply, but based on the material measured in the snowpack and lake ice, we are confident that the amount is not significant.

From our point of view there are two main reasons for relatively little aeolian supply to Lake El'gygytgyn. First, the El'gygytgyn Crater is comparably small and a closed trap for aeolian material and secondly, the predominant wind directions either from the Arctic or the Pacific Oceans exclude widespread source areas for aeolian material.

\subsubsection{Delivery of coarse-grained debris into the Lake}

To be clear, we estimated only suspended fluvial sediment input to the lake and did not measure river-bed sediment load. These kinds of measurements require complex equipment and longer observation periods beyond what was possible 
in this remote region. During most of the active fluvial period, delivery of coarse-grained material into the coastal zone is a slow process, but, as observed in spring (June) 2003, it becomes significantly more active during the very short spring freshets. At the onset of the snow-melting period streams immediately become active, at a time, when the lake is still covered by thick ice (up to $2 \mathrm{~m}$ ). During these periods the largest streams formatting fans consists of sand, gravel and cobbles extending up to hundreds of meters onto the lake ice. This process influences the shallow-water environment of the lake via the delivery of coarse-grained material into subaquatic portions of the alluvial fans. However, due to the active movement of the lake ice cover during summer (July), entrained coarse-grained material can melt out in deeper parts of the lake, thus producing "drop-stones" in pelagic sediments.

\subsubsection{Coastal zone as a trap for incoming sediments}

Since lake level is largely regressive in character, the modern coastal zone is prograding except where it is annually deformed by ice shove events. Very common features for the modern shoreline are gravel berms formed by wave activity that effectively trap coarse-grained material supplied to the lake. Many of the stream mouths are impounded by such berms, causing lagoons to form behind them. These lagoons act as traps for fine-grain sediment as well. Total lagoon area calculated for 2000 was $11.5 \pm 1.0 \mathrm{~km}^{2}$ (Nolan and BrighamGrette, 2007), which is just 10 times less than lake surface. The area was calculated for mid-summer and, of course, it is much larger during snowmelt. The slope mass wasting delivered into the lake is also dammed by these berms (Schwamborn et al., 2008; Fedorov et al., 2008). This kind of coastal zone activity coincided with lake-level lowering stages. During rising lake level stages, erosion increases in the coastal zone evoking the destruction of the gravel berms and levees as the lagoons overflow. This provides a significant amount of debris in a short time period onto the proximal parts of alluvial fans, which are otherwise the primary source for debris flows and turbidities recognized in lake sediment cores (Juschus et al., 2009; Sauerbrey et al., 2013).

\subsection{Sources of uncertainty}

Here we highlight the preliminary character of our estimates and mention the main sources of uncertainties in our calculations:

a. The highest uncertainty, we admit, is probably related to the fact that our data are limited to one year only, 2003, which up to now is the only year water discharge data including both spring flooding and summer period are available. b. Our calculations are based on only three series of the measurements - one during spring flooding and two during the summer season.

c. We extrapolated the calculated unit area of discharge for measured streams to the entire watershed area, without taking into consideration the topography of each stream drainage basin.

d. The amount of the liquid precipitation on the ice-free lake has been estimated based on data from just one automatic meteorological station installed on the southern lake shore. This neglects heterogeneities in local precipitation, however, our own meteorological data are believed to be much more reliable than data from regular meteorological stations, which are sparsely distributed in Chukotka.

e. Evaporation from the open-water surface has been estimated based on standard regional data from 1964. Taking into account the extent of climate change since then, these data most likely do not fully represent the modern climate situation.

\section{Conclusions}

1. The first quantitative estimates of the Lake El'gygytgyn water balance and sediment income are provided as a baseline for future work. All calculations in this research are admittedly rough and have a high level of uncertainties due to field limitations, but even this level of new knowledge is extremely important as basic information for the paleoenvironmental interpretations of the sedimentary record.

2. Lake El'gygytgyn is a typical arctic nival hydrological regime. Surface drainage system is active only during the short summer and many of the inlet streams are active mostly during snowmelt when water and sediment input is an order of magnitude higher than that during summer.

3. Underground runoff from the lake is active in summer and persists even during winter at the lake outlet. The latter is clearly indicated by annual aufeis formation. This occurs because the modern lake level is higher than the bedrock outflow threshold, which was likely eroded to about $10 \mathrm{~m}$ below modern water level during the Late Weichselian and is now covered by porous lacustrinefluvial sediments (Schwamborn et al., 2008; Fedorov et al., 2008; Juschus et al., 2011).

4. The residence time of the lake under modern conditions is estimated to be $\sim 100 \mathrm{yr}$. 
5. The overwhelming amount of sediment transported into the lake is accomplished by the inlet streams. Aeolian input is not significant; rather it amounts to only a few percent of the total input.

6. Modern times can presumably be thought of as representative of Quaternary interglacial and interstadial settings, being characterized by a semi-permanent lakeice cover, mass wasting and the fluvial delivery of sediment into the lake. Significant is the role of coastal berms and levees in trapping material landward of beach in lagoons.

Acknowledgements. We would like to thank the funding agencies including the International Continental Scientific Drilling Program (ICDP), German Federal Ministry of Education and Research (BMBF; grants 03G0586 and 03G0642), US National Science Foundation (grants OPP 007122, 96-15768, and 0002643), Russian Academy of Sciences, Austrian Federal Ministry of Science and Research and all the participants of the international "El'gygytgyn Drilling Project" for support and collaborations. Field work was also supported by a governmental grant of the Russian Federation (grant 11.G34.31.0025). We are also grateful to the Russian Foundation of Basic Research (grant 10-05-00235-a) and the Russian-German Otto Schmidt Laboratory for supporting the analytical work.

Edited by: M. Melles

\section{References}

Belyi, V. F.: Impactogenesis and volcanism of the El'gygytgyn depression, Petrology, 6, 86-99, 1998.

Brigham-Grette, J., Melles, M., Minyuk, P., Andreev, A., Tarasov, P., DeConto, R., Koenig, S., Nowaczyk, N., Wennrich, V., Rosén, P., Haltia, E., Cook, T., Gebhardt, C., Meyer-Jacob, C., Snyder, J., and Herzschuh, U.: Pliocene warmth, polar amplification, and stepped Pleistocene cooling recorded in NE Arctic Russia, Science Express, 9 May, 2013.

Fedorov, G. B., Schwamborn, G., and Bolshiyanov, D. Y.: Late Quaternary lake level changes at Lake El'gygytgyn, Bulletin of St. Petersburg State University, Series-7, 1, 73-78, 2008 (in Russian)

Glotov, V. Y. and Zuev, S. A.: Hydro-geological features of the El'gygytgyn Lake, Kolyma, 3-4, 18-23, 1995 (in Russian).

Glushkova, O. Y.: Geomorphology and the history of the relief development of the El'gygytgyn lake region, in: The nature of the El'gygytgyn lake basin (problems of study and preservation), NEISRI FEB RAS, Magadan, 26-48, 1993 (in Russian).

Guide to hydrometeorological stations, Ed. 6, Part 1, Gidrometizdat, Leningrad, 384 pp., 1978 (in Russian).

Juschus, O., Melles, M., Gebhardt, C., and Niessen, F.: Late Quaternary mass movement events in Lake Elgygytgyn, North-eastern Siberia, Sedimentology, 56, 2155-2174, doi:10.1111/j.13653091.2009.01074.x, 2009.
Juschus, O., Pavlov, M., Schwamborn, G., Federov, G., and Melles, M.: Lake Quarternary lakelevel changes of Lake El'gygytgyn, NE Siberia, Quarternary Res., 76, 441-451, 2011.

Kohzevnikov, Yu. P.: Vascular plants in the vicinities of the Elgygytgyn Lake, in: The Nature of the El'gygytgyn Lake Hollow, edited by: Bely, V. F. and Chereshnev, I. A., NEISRI FEB RAS Magadan, 62-82, 1993 (in Russian).

Layer, P.: Argon-40/argon-39 age of the El'gygytgyn impact event, Chukotka, Russia, Meteorit. Planet. Sci., 35, 591-599, 2000.

Lozhkin, A. V., Anderson, P. M., Matrosova, T. V., and Minyuk, P. S.: The pollen record from El'gygytgyn Lake: implications for vegetation and climate histories of northern Chukotka since the late middle Pleistocene, J. Paleolimnol., 37, 135-153, doi:10.1007/s10933-006-9018-5, 2006.

Melles, M., Brigham-Grette, J., Minyuk, P., Koeberl, C., Andreev, A., Cook, T., Fedorov, G., Gebhardt, C., HaltiaHovi, E., Kukkonen, M., Nowaczyk, N., Schwamborn, G., Wennrich, V. and El'gygytgyn Scientific Party: The El'gygytgyn Scientific Drilling Project - conquering Arctic challenges through continental drilling, Sci. Drill., 11, 29-40, doi:10.2204/iodp.sd.11.03.2011, 2011.

Melles, M., Brigham-Grette, J., Minyuk, P. S., Nowaczyk, N. R., Wennrich, V., DeConto, R. M. Anderson, P. M., Andreev, A. A., Coletti, A., Cook, T. L., Haltia-Hovi, E., Kukkonen, M., Lozhkin, A. V., Rosén, P., Tarasov, P., Vogel, H., and Wagner, B.: 2.8 million years of Arctic climate change from Lake El'gygytgyn, NE Russia, Science, 337, 315-320, doi:10.1126/science.1222135, 2012.

Minyuk, P. S.: Vegetation around Lake El'gygytgyn, in: The expedition El'gygytgyn Lake 2003 (Siberian Arctic), Vol. 509, edited by: Melles, M., Minyuk, P. S., Brigham-Grette, J., and Juschus, O., 30-35, 2005.

Mottaghy, D., Schwamborn, G., and Rath, V.: Past climate changes and permafrost depth at the Lake El'gygytgyn site: implications from data and thermal modeling, Clim. Past, 9, 119-133, doi:10.5194/cp-9-119-2013, 2013.

Nolan, M.: Analysis of local AWS and NCEP/NCAR reanalysis data at Lake El'gygtytgyn, and its implications for maintaining multi-year lake-ice covers, Clim. Past Discuss., 8, 1443-1483, doi:10.5194/cpd-8-1443-2012, 2012.

Nolan, M. and Brigham-Grette, J.: Basic hydrology, limnology, and meterology of modern Lake El'gygytgyn, Siberia, J. Paleolimnol., 37, 17-35, 2007.

Nolan, M., Liston, G., Prokein, P., Brigham-Grette, J., Sharpton, V., and Huntzinger, R.: Analysis of Lake Ice Dynamics and Morphology on Lake El'gygytgyn, Siberia, using SAR and Landsat, J. Geophys. Res., 108, 8162, doi:10.1029/2001JD000934, 2003.

Sauerbrey, M. A., Juschus, O., Gebhardt, A. C., Wennrich, V., Nowaczyk, N. R., and Melles, M.: Mass movement deposits in the 3.6 Ma sediment record of Lake El'gygytgyn, Far East Russian Arctic: classification, distribution and preliminary interpretation, Clim. Past Discuss., 9, 467-505, doi:10.5194/cpd-9-4672013, 2013.

Schwamborn, G., Fedorov, G., Schirrmeister, L., Meyer, H., and Hubberten, H.-W.: Periglacial sediment variations controlled by Late Quaternary climate and lake level rise at Elgygytgyn Crater, Arctic Siberia, Boreas, 37, 55-65, 2008. 
Schwamborn, G., Fedorov, G., Ostanin, N., Schirrmeister, L., Andreev, A., and the El'gygytgyn Scientific Party: Depositional dynamics in the El'gygytgyn Crater margin: implications for the 3.6 Ma old sediment archive, Clim. Past, 8, 1897-1911, doi:10.5194/cp-8-1897-2012, 2012.

Sokolov, A. A.: Hydrography of USSR, GIMIZ, Lenigrad, 535 pp., 1964 (in Russian).

Wilkie, K. M. K., Chapligin, B., Meyer, H., Burns, S., Petsch, S., and Brigham-Grette, J.: Modern isotope hydrology and controls on $\delta \mathrm{D}$ of plant leaf waxes at Lake El'gygytgyn, NE Russia, Clim. Past, 9, 335-352, doi:10.5194/cp-9-335-2013, 2013.

Woo, M. Kane, D., Carey, S., and Yang, D.: Progress in Permafrost Hydrology in the New Millennium, Permafrost Periglac., 19, 237-254, 2008.

Yershov, E. D.: General Geocryology. Studies in Polar Research, Cambridge Univ. Press, English Edn., 1998.
Yurtsev, B. A.: Botanic-geographical zonation and floristic zoning of the tundra in Chukotka, J. Bot., 58, 812-821, 1973 (in Russian).

Zhang, Y., Ohata, T., and Kadota, T.: Land-surface hydrological processes in the permafrost region of the eastern Tibetan Plateau, J. Hydrol., 283, 41-56, 2003.

Zimichev, V. P., Bolshiyanov, D. Y., Mesheryakov, V. G., and Gintz, D.: The features of the hydrological regime of the lake-river systems of the Byrranga Mountains (by example of the LevinsonLessing Lake), in: Land-Ocean Systems in the Siberian Arctic, Dynamics and History, edited by: Kassens, H., Bauch, H. A., Dmitrenko, I., Eicken, H., Hubberten, H.-W., Melles, M., Thiede, J., and Timokhov, L., Springer-Verlag, Berlin, 353-360, 1999. 